\title{
Antibiotic susceptibility and biochemical properties of Streptococcus faecalis strains reacting with both D and $\mathrm{G}$ antisera
}

\author{
BR BIRCH, MAEVE GL KEANEY, LEELA A GANGULI \\ From the Department of Medical Microbiology, Hope Hospital, University of Manchester School of \\ Medicine, Salford M6 $8 H D$
}

SUMMARY Thirty one of 60 consecutive isolates of Streptococcus faecalis produced a reaction in both $D$ and $G$ streptococcal grouping sera. A close correlation was found between this grouping reaction and haemolysin production, resistance to erythromycin, tetracycline, and trimethoprim, and delayed fermentation of sorbitol.

Enterococci, or faecal streptococci of Lancefield group D, are common inhabitants of the gastrointestinal tract in man and in a wide variety of animals. As a result of faecal contamination they are widely distributed in nature and survive well on growing vegetation. ${ }^{1}$ These organisms are frequent causes of urinary tract infection, ${ }^{2}$ less common causes of endocarditis ${ }^{3}$ and meningitis, ${ }^{4}$ and are generally considered to be of low pathogenic potential. Their frequent occurrence in clinical material is thought to reflect local carriage of the organisms at various sites in the body. ${ }^{5}$

Streptococcus faecalis is the commonest member of the faecal streptococci found in the human gut. ${ }^{6}$ Deibel and Seeley have subspeciated Str faecalis into subspecies faecalis, zymogenes, and liquefaciens based on haemolysin production and gelatin liquefaction. The validity of this is questioned in view of the instability of gelatinase production ${ }^{18}$ and the plasmid borne nature of $\beta$-haemolysis.9 Str faecium, the other common faecal streptococcus in man, is still considered to be taxonomically distinct from Str faecalis, as is the non-enterococcal group D organism Str bovis. ${ }^{10}$

In a recent study we found that about half of the enterococcal isolates from the Salford area react with both group D and G antisera. " The antigenic determinant of group $D$ streptococci is a glycerol teichoic acid located between the cell wall and membrane, ${ }^{12}$ unlike most other serological groups, including group $G$, where it is a cell wall polysaccharide. ${ }^{13}$ Only occasional strains of Str faecalis have previously been reported to give this reaction and

Accepted for publication 15 August 1984 these strains possessed the group $G$ carbohydrate antigen. ${ }^{14}$ This report defines the local occurrence of these strains, describes their cultural and biochemical characteristics, and reports on their antibiotic susceptibility.

\section{Material and methods}

\section{ORGANISMS}

Sixty two consecutive clinical isolates of faecal type streptococci were tested. Two isolates, subsequently identified as Str faecium, were excluded from the study. The strains were isolated, often in mixed culture, from wounds and urine samples. Specimens came from five hospitals in the Salford district and also from general practice patients. Strains were stored at $-76^{\circ} \mathrm{C}^{15}$ before testing.

\section{SEROLOGICAL GROUPING}

The Lancefield group of the test strains was determined by four different techniques:

1 An autoclave extraction method ${ }^{16}$ using an overnight culture in brain heart infusion broth (Lab $M$, Code lab 49).

2 A Streptomyces albus enzyme extraction procedure $^{17}$ using a commercial enzyme preparation (Difco, Code 3134).

3 A commercial latex agglutination method (Streptex, Wellcome Diagnostics, Code ZL01).

4 A commercial coagglutination method (Phadebact, Pharmacia Ltd, Codes 22, 23).

In methods 1 and 2 streptococcal extracts were carefully layered on to grouping antisera (Wellcome Diagnostics) in small glass tubes of $4 \mathrm{~mm}$ internal diameter and examined for lines of precipitation 
after $15 \mathrm{~min}$ and $1 \mathrm{~h}$. In methods 3 and 4 grouping was performed strictly in accordance with the manufacturers' instructions.

\section{BIOCHEMICAL IDENTIFICATION}

Isolates were cultured on Columbia agar (Lab $\mathrm{M}$, Code lab 1) containing 5\% defibrinated horse blood and incubated aerobically overnight at $37^{\circ} \mathrm{C}$. Growth was harvested using a sterile cotton wool swab and suspended in $2 \mathrm{ml}$ of distilled water. API 20 Strep galleries (API Code 2060) were then inoculated according to the manufacturer's instructions and incubated at $37^{\circ} \mathrm{C}$. These were examined after $4 \mathrm{~h}$ incubation, after the addition of reagents, and again after overnight incubation. The inoculum was checked for purity on Columbia blood agar and the presence or absence of haemolysis was noted.

\section{ANTIBIOTIC DISC SUSCEPTIBILITY}

Disc susceptibility tests were performed on sulphonamide antagonist free medium (SAF, Mast Laboratories, Code DM215) with 5\% lysed horse blood using Staphylococcus aureus NCTC 6571 as a control. A modified Stokes' method of inoculation was used. ${ }^{18}$ The antibiotics tested were penicillin G $2 \mu \mathrm{g}$, ampicillin $10 \mu \mathrm{g}$, erythromycin $5 \mu \mathrm{g}$, tetracycline $10 \mu \mathrm{g}$, chloramphenicol $10 \mu \mathrm{g}$, sulphamethoxazole $100 \mu \mathrm{g}$, trimethoprim $1.25 \mu \mathrm{g}$, lincomycin $2 \mu \mathrm{g}$, clindamycin $2 \mu \mathrm{g}$, vancomycin $10 \mu \mathrm{g}$ (all from Oxoid Ltd), and rifampicin $2 \mu \mathrm{g}$ (Mast Laboratories).

\section{MINIMUM INHIBITORY CONCENTRATIONS}

Plate minimum inhibitory concentrations were determined in SAF medium with $5 \%$ lysed horse blood. The antibiotics tested were erythromycin, tetracycline, and trimethoprim (Adatabs, Mast Laboratories). The inoculum was a $4 \mathrm{~h}$ culture of the test strain in Iso-sensitest broth (Oxoid, Code CM 473) using a multipoint inoculator (Denley Ltd). Staph aureus NCTC 6571 was used as a control. The minimum inhibitory concentration was defined as the lowest concentration of antibiotic which completely inhibited growth.

\section{Results}

\section{SEROLOGICAL GROUPING}

Of the 60 test strains, $29(48.3 \%)$ reacted with group D antiserum alone and $31(51.7 \%)$ reacted with both $D$ and $G$. In many strains the group $G$ reaction was the stronger of the two. Results were identical with all four grouping methods, although the autoclave extraction method gave the weakest reactions in both $D$ and $G$. Methods 1 and 2 gave poor precipitin lines with group $\mathrm{D}$ antisera.
Table 1 Haemolytic reactions and $24 h$ sorbitol fermentations in 60 Streptococcus faecalis strains

\begin{tabular}{lcc}
\hline & $\beta$-haemolysis & Sorbitol \\
\hline Group $D(n=29)$ & $4(13.8 \%)$ & $29(100 \%)$ \\
Group $D / G(n=31)$ & $27(87.1 \%)$ & $8(25 \cdot 8 \%)$ \\
\hline
\end{tabular}

\section{BIOCHEMICAL IDENTIFICATION}

All group D strains were identified as Str faecalis by the API 20 Strep system as opposed to only 8 $(25.8 \%)$ of the $31 \mathrm{D} / \mathrm{G}$ strains (Table 1$)$. The D/G strains which could not be speciated by the API system were biochemically identical to Str faecalis in all respects except for failure to produce acid from sorbitol at $4 \mathrm{~h}$ or after overnight incubation. Acid production from sorbitol could be shown, however, if the API galleries were incubated for a further $24 \mathrm{~h}$.

Only four $(13.8 \%)$ of the group D strains showed $\beta$-haemolysis, whereas this characteristic was shown by most $(87 \cdot 1 \%)$ of the $D / G$ strains (Table 1$)$.

\section{ANTIBIOTIC SUSCEPTIBILITY AND MINIMUM INHIBITORY CONCENTRATIONS}

All strains were uniformly sensitive to ampicillin and vancomycin and resistant to penicillin $G$, sulphamethoxazole, lincomycin, clindamycin, and rifampicin. Six of the 60 strains were resistant to chloramphenicol (four group $D$, two group $D / G$ ). The sensitivity to erythromycin, tetracycline, and trimethoprim was variable.

On minimum inhibitory concentration testing we noted high level resistance to erythromycin and tetracycline in the $D / G$ strains. The minimum inhibitory concentration to trimethoprim was also higher in most of these strains (Table 2).

\section{Discussion}

$D / G$ strains now account for more than half of our isolates of faecal streptococci. Informal inquiries indicate that these strains are also encountered in other parts of the Greater Manchester area but are less common in the rest of the UK. Detailed records of streptococcal grouping results, which have been kept in our laboratory since 1978 , show that this phenomenon was first noted in May 1983. Several strains have initially been wrongly identified as Lancefield group $G$ until subsequent identification has shown them to be Str faecalis. The potential for misidentification would be further enhanced in laboratories using the Phadebact Kit, in which the group $D$ antiserum is omitted from the basic reagent set, although it may be purchased as a separate item. Most laboratories do not routinely identify or serologically classify faecal streptococci but these 
Table 2 Number (\%) of Streptococcus faecalis strains with specific minimum inhibitory concentrations to erythromycin, tetracycline, and trimethoprim

\begin{tabular}{|c|c|c|c|c|c|c|c|c|c|c|}
\hline & \multicolumn{10}{|c|}{ Minimum inhibitory concentrations (mgll) } \\
\hline & $\leqslant 0.3$ & 0.6 & 1.25 & $2 \cdot 5$ & 5 & 10 & 20 & 40 & 80 & $>80$ \\
\hline $\begin{array}{c}\text { Erythromycin } \\
\text { Group D } \\
(\mathrm{n}=29) \\
\text { Group D/G } \\
(\mathrm{n}=31) \\
\text { Tetracycline }\end{array}$ & & $\begin{array}{l}1 \\
(3 \cdot 4)\end{array}$ & $\begin{array}{l}2 \\
(6 \cdot 9)\end{array}$ & $\begin{array}{l}5 \\
(17 \cdot 2) \\
1 \\
(3 \cdot 2)\end{array}$ & $\begin{array}{l}8 \\
(27.5)\end{array}$ & $\begin{array}{l}5 \\
(17 \cdot 2) \\
4 \\
(12 \cdot 9)\end{array}$ & $\begin{array}{l}1 \\
(3 \cdot 4)\end{array}$ & $\begin{array}{l}2 \\
(6 \cdot 9)\end{array}$ & $\begin{array}{l}1 \\
(3 \cdot 4) \\
1 \\
(3 \cdot 2)\end{array}$ & $\begin{array}{l}4 \\
(13 \cdot 8) \\
25 \\
(80-6)\end{array}$ \\
\hline $\begin{array}{l}\text { Group D } \\
\text { Group D/G }\end{array}$ & & & $\begin{array}{l}1 \\
(3 \cdot 4)\end{array}$ & $\begin{array}{l}7 \\
(24 \cdot 1) \\
1 \\
(3 \cdot 2)\end{array}$ & $\begin{array}{l}2 \\
(6 \cdot 9) \\
1 \\
(3 \cdot 2)\end{array}$ & & & & & $\begin{array}{l}19 \\
(65 \cdot 5) \\
29 \\
(93.5)\end{array}$ \\
\hline $\begin{array}{c}\text { Trimethoprim } \\
\text { Group D } \\
\text { Group D/G }\end{array}$ & $\begin{array}{l}17 \\
(58 \cdot 6) \\
3 \\
(9 \cdot 7)\end{array}$ & $\begin{array}{l}3 \\
(10 \cdot 3) \\
1 \\
(3 \cdot 2)\end{array}$ & $\begin{array}{l}5 \\
(17 \cdot 2) \\
8 \\
(25 \cdot 8)\end{array}$ & $\begin{array}{l}3 \\
(10-3) \\
18 \\
(58 \cdot 1)\end{array}$ & & $\begin{array}{l}1 \\
(3 \cdot 2)\end{array}$ & & $\begin{array}{l}1 \\
(3 \cdot 4)\end{array}$ & & \\
\hline
\end{tabular}

$D / G$ strains show wide zones of $\beta$-haemolysis and their colonial morphology closely resembles that of pyogenic groups A, C, and G.

Paull and Farrar ${ }^{13}$ encountered a small number of "cross reacting" strains when evaluating the modified Streptex grouping kit. They state, however, that these strains gave only a group $D$ reaction using the Rantz and Randall ${ }^{16}$ autoclave extraction technique. They believed that this anomaly was due to the high degree of efficiency of the Streptex extraction enzyme. As we could detect the group $G$ antigen after autoclave extraction, it is not clear whether our strains correspond to those previously described. The group specific carbohydrate in conventional group G streptococci consists of rhamnose, galactose, and galactosamine. ${ }^{19}$ Cell wall studies on our D/G strains would show whether they produce similar carbohydrate antigens or other substances which may act antigenically in a similar way.

At first, it was thought that the $D / G$ strains failed to ferment sorbitol and, because of this, they were not represented in the API data base code book. Once it was realised that sorbitol was fermented, albeit slowly, these strains conformed to the description of Str faecalis. Retrospectively, six representative strains each of groups $D$ and $D / G$ have been tested in API 50CH galleries, which provide a total of 49 substrates. Delayed sorbitol fermentation remained the only aberrant biochemical reaction distinguishing the two groups (unpublished data). The importance of the apparently close link between grouping reaction and late fermentation of sorbitol is unclear.

The link between grouping reaction and production of $\beta$-haemolysis is striking. These haemolytic strains would, using traditional taxonomic criteria, have been considered to be the zymogenes variety of Str faecalis. There is, however, no apparent sugges- tion in published descriptions of this variant that any serological anomalies have been noted. Jacob et al ${ }^{9}$ showed that haemolysin production was invariably due to a self transferable plasmid. The importance of the apparent link between grouping reaction and production of $\beta$-haemolysis is, at present, unknown, although we are investigating the possibility that the doubly reacting property is plasmid mediated.

The $D / G$ strains appear to show a higher level of resistance to certain antibiotics than the conventional group D strains. This is true of erythromycin and tetracycline, and, although minimum inhibitory concentrations to trimethoprim are not particularly high, they are several orders of magnitude greater than those shown by most group D strains. Preliminary studies on 12 strains have indicated that minimum inhibitory concentrations to gentamicin of six $D / G$ strains are in excess of $2000 \mathrm{mg} / \mathrm{l}$, as opposed to about 8 or $16 \mathrm{mg} / \mathrm{l}$ in six group D organisms (unpublished data). The presence of Str faecalis in clinical material seldom warrants the use of antimicrobial agents. The therapeutic implications of these resistant D/G strains may, however, be of considerable importance in the treatment of endocarditis. It has previously been shown that resistance to tetracycline and erythromycin in Streptococcus faecalis may be plasmid mediated ${ }^{2021}$ and this possibility is also being investigated in our $D / G$ strains.

We thank the staff of our department for collecting the Str faecalis strains and Mrs Margaret Marriott for typing the manuscript.

\footnotetext{
References

' Deibel RH. The Group D streptococci. Bacteriol Rev 1964;28:330-66.

${ }^{2}$ Foley GE. Further observations on the occurrence of strep-
} 
tococci of Groups other than A in human infection. N Engl J Med 1947;237:809-11.

${ }^{3}$ Uwaydah MM, Weinberg AN. Bacterial endocarditis-a changing pattern. $N$ Engl J Med 1965;273:1231-5.

${ }^{4}$ Bayer AS, Seidel JS, Yoshikawa TT, Anthony BF, Guze LB. Group D enterococcal meningitis. Arch Intern Med 1976;136:883-6.

${ }^{5}$ Parker MT. The pattern of streptococcal disease in man. In: Skinner FA, Quesnel LB, eds. Streptococci. Society for Applied Bacteriology Symposium Series No 7. London: Academic Press, 1978:71-106.

- Andrewes FW, Horder J. A study of the Streptococci pathogenic for man. Lancet 1906;ii: 708-13:775-82:852-5.

' Deibel RH, Seeley HW. Streptococcacae fam nov. In: Buchanan RE, Gibbons NE, eds. Bergey's manual of determinative bacteriology. Baltimore: Williams and Wilkins, 1974:490-517.

8 Jones D, Sackin MJ, Sneath PHA. A numerical taxonomic study of streptococci of serological group D. J Gen Microbiol 1972; 72:439-50.

9 Jacob AE, Douglas GJ, Hobbs SJ. Self-transferable plasmid determining the haemolysin and bacteriocin of Streptococcus faecalis var zymogenes. J Bacteriol 1975;121:863-72.

${ }^{10}$ Jones D. Composition and differentiation of the genus Streptococcus. In: Skinner FA, Quesnel LB, eds. Streptococci. Society for Applied Bacteriology Symposium Series no 7. London: Academic Press, 1978:1-49.

" Birch BR, Keaney MGL, Ganguli LA. Streptococcus faecalis: Group D or Group G? Letter. Lancet 1984;i:856.

12 Jones D, Shattock PMF. The location of the group antigen of Group D Streptococci. J Gen Microbiol 1960;23:335-43.

${ }^{13}$ Lancefield RC. A serological differentiation of human and other groups of haemolytic streptococci. J Exp Med 1933;57:57195.

${ }_{14}$ Paull A, Farrar JL. A comparative study of a modified Streptex streptococcal grouping technique with a conventional grouping method. In: Holm SE, Christensen P, eds. Basic concepts of streptococci and streptococcal diseases. Chertsey, Surrey: Reedbooks Ltd, 1982:43-4.

is Feltham RKA, Power AK, Pell PA, Sneath PHA. A simple method for storage of bacteria at $-76^{\circ} \mathrm{C}$. J Appl Bacteriol $1978 ; 44: 313-6$.

${ }^{16}$ Rantz LA, Randall E. Use of autoclaved extracts of hemolytic streptococci for serological grouping. Stanford Med Bull 1955;13:290-1.

17 Maxted WR. Preparation of Streptococcal extracts for Lancefield grouping. Lancet 1948;ii:255-6.

${ }^{18}$ Pearson CH, Whitehead JEM. Antibiotic sensitivity testing: a modification of the Stokes method using a rotary plater.J Clin Pathol 1974;27:430-1.

${ }^{19}$ Curtis SN, Krause RM. Immunochemical studies on the specific carbohydrate of Group G Streptococci. J Exp Med 1964;119:997-1004.

${ }^{20}$ Jacob AE, Hobbs SJ. Conjugal transfer of plasmid-borne multiple antibiotic resistance in Streptococcus faecalis var zymogenes. J Bacteriol 1974; 117:360-72.

${ }^{21}$ Clewell DB, Yagi Y, Dunny GM, Schulz SK. Characterisation of three plasmid deoxyribonucleic acid molecules in a strain of Streptococcus faecalis: identification of a plasmid determining erythromycin resistance. J Bacteriol 1975; 117:283-9.

22 Courvalin PM, Carlier C, Chabbert YA. Plasmid-linked tetracycline and erythromycin resistance in group D Streptococcus. Ann Inst Pasteur 1972;123:755-9.

Requests for reprints to: Mr BR Birch, Department of Medical Microbiology, Hope Hospital, University of Manchester School of Medicine, Salford M6 8HD, UK. 